\title{
A phylogeographic break and bioacoustic intraspecific differentiation in the Buff-barred Warbler (Phylloscopus pulcher) (Aves: Passeriformes, Phylloscopidae)
}

\author{
Martin Päckert ${ }^{1 *}$, Yue-Hua Sun ${ }^{2 *}$, Balduin S Fischer ${ }^{3}$, Dieter Thomas Tietze ${ }^{4}$ and Jochen Martens ${ }^{5}$
}

\begin{abstract}
Background: According to current taxonomy only three out of 27 Sinohimalayan leaf warbler species (Phylloscopidae) are considered genetically uniform across their entire breeding range along the Southeastern margin of the Qinghai-Tibetan Plateau, the Buff-barred Warbler (Phylloscopus pulcher) being one of them. Because marked differentiation among Himalayan and Chinese populations has been recently demonstrated for a number of Phylloscopus species (or sister species) we investigated the intraspecific variation of a mitochondrial gene, songs and morphology of $P$. pulcher in a phylogeographic approach.
\end{abstract}

Methods: We sequenced a fragment of the mitochondrial cytochrome $b$, reconstructed haplotype networks and analyzed DNA polymorphism among Himalayan and Chinese populations. We measured time and frequency parameters of two distinct song types and analyzed among population-differentiation in a principal component analysis and a discriminant analysis. We also compared measurements of body size dimensions taken from museum specimens.

Results: The mitochondrial haplotype network (cytb) was divided into two distinct clusters corresponding to geographic origin of samples. Pairwise genetic distances among Himalayan and Chinese mtDNA lineages account for $1.3 \%$ which coincides with Pleistocene lineage separation at roughly 650,000 years ago. Genetic diversity is slightly higher in the Chinese part of the species' range with respect to haplotype and nucleotide diversity while the less diversified Himalayan population lineage shows signs of recent range expansion. The vocal repertoire of P. pulcher comprises two distinct verse types that are combined with short interspersed click notes to long continuous song displays. Trill verse types showed significant differences among regions in almost all measured frequency and time parameters: Chinese males displayed more rapid and more broad-banded trills at a lower pitch. In contrast, warbling verse types showed a distinctively different structure among regions: Himalayan songs consisted of repeated syllables while Chinese songs comprised repetitions of single, long and strongly modulated elements. Subtle morphological differences among specimens from the two study regions could only be confirmed for plumage coloration but not for metric characters.

Conclusions: Based on the genetic and bioacoustic distinctiveness of Chinese Buff-barred Warbler populations, we recommend that the name Phylloscopus pulcher vegetus Bangs, 1913 should be re-validated for this taxon.

Keywords: Phylloscopidae, Phylogeography, East-west divide, Territorial songs, Phylloscopus pulcher vegetus

\footnotetext{
*Correspondence: martin.paeckert@senckenberg.de; sunyh@ioz.ac.cn

'Senckenberg Natural History Collections, Museum of Zoology,

Königsbrücker Landstraße 159, D-01109 Dresden, Germany

${ }^{2}$ Key Laboratory of Animal Ecology and Conservation, Institute of Zoology,

Chinese Academy of Science, 100101 Beijing, China

Full list of author information is available at the end of the article
}

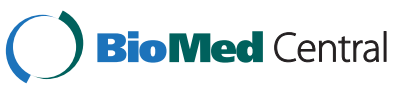

(C) 2014 Päckert et al.; licensee BioMed Central Ltd. This is an Open Access article distributed under the terms of the Creative Commons Attribution License (http://creativecommons.org/licenses/by/4.0), which permits unrestricted use, distribution, and reproduction in any medium, provided the original work is properly credited. The Creative Commons Public Domain Dedication waiver (http://creativecommons.org/publicdomain/zero/1.0/) applies to the data made available in this article, unless otherwise stated. 


\section{Background}

Phylogeographic patterns of Sino-Himalayan forest passerines are widely congruent for terminal sister taxa equally on the species level as well as on the subspecies level (Martens et al. 2011; Päckert et al. 2012). The consistency of these patterns across different passerine families implies a common onset and cause of differentiation among the extant taxa concerned: Of many Chinese bird species (particularly of those occupying subalpine breeding habitats) their closest relative inhabits the corresponding elevational forest belt of the Himalayas and/or the adjacent Indo-Burmese mountain ranges. In many cases the origin of the respective sister lineage split and extant vicariance could be dated back to Pleistocene range fragmentation (Päckert et al. 2009a, 2012). So far, information on the extent of secondary contact zones among such close, but genetically distinct relatives is scarce except for several sister taxa in the Himalayas (Martens and Eck 1995; Martens et al. 2011; Päckert et al. 2012). Recent phylogeographic studies on Chinese bird populations even located some areas of range overlap at the south-eastern margin of the Qinghai-Tibetan Plateau (QTP) in the Hengduan mountain range that in some cases well correspond with the postulated Mekong-Salween divide (Dai et al. 2011; Zhao et al. 2012). Likewise, similar phylogeographic breaks have been found across the Himalayas at the southern QTP margin, e.g. between Himalayan and Indo-Burmese sister lineages (Päckert et al. 2012) and even for Central Nepal four distinct subspecies transition areas were defined by (Martens and Eck (1995); (Figure Forty-one)).

Among a large number of phylogenetic and phylogeographic studies of Asian birds, leaf warblers (Phylloscopidae; sensu Alström et al. 2006; taxonomic review in Martens 2010) are among the best studied families. To date, nearly all currently accepted Asian species have been firmly placed in a molecular phylogeny (Johansson et al. 2007; Price 2010; Päckert et al. 2012; Alström et al. 2013) and phylogeographic relationships among close relatives of single subclades have been evaluated (Helbig et al. 1995, 1996; Irwin et al. 2001a, 2001b, 2005; Martens et al. 2004, 2008; Olsson et al. 2004, 2005; Päckert et al. 2004, 2009b; Rheindt 2006) including several recent descriptions of new species from China, Vietnam and Laos (Martens et al. 1999; Alström and Olsson 1999; Martens et al. 2008; Alström et al. 2010). Many species and subspecies pairs of Phylloscopus leaf warblers reflect a common phylogeographic pattern of East-West splits between Chinese and Himalayan sister species with most of them corresponding to genetic distances between 1\% and 3\% (late to early Pleistocene divergence according to the revisited molecular clock for avian cytochrome $b$ by Weir and Schluter 2008; Table 1) and only a few dating back to earlier periods of lineage separation (e.g. subspecies of $P$. humei, $P$. affinis/P. occisinensis, Table 1). These phylogeographic East-West divides at the southern/ south-eastern QTP margin appear to be a quite universal pattern not only in leaf warblers and it is remarkable that among 27 Chinese and Himalayan Phylloscopus species (Clements et al. 2013), only three are currently considered genetically uniform without any notable internal splits across a wide trans-Sino-Himalayan range: the Ashythroated Leaf Warbler (Phylloscopus maculipennis), the Large-billed Leaf Warbler (Phylloscopus magnirostris) and the Buff-barred Warbler (Phylloscopus pulcher).

The Buff-barred Warbler (Phylloscopus pulcher; sometimes also named Orange-barred Leaf Warbler) occupies a wide breeding distribution from the NW Himalayas along the southern margin of the Qinghai-Tibetan Plateau to the Hengduan Mountains and stretching to $\mathrm{N}$ and $\mathrm{E}$ Myanmar and to SW and C China (map with detailed records in von Vietinghoff-Scheel 1984; Cheng 1987; Clement 2006; Martens 2010). Within the wide breeding range two subspecies are currently accepted (Clement 2006; Martens 2010): Phylloscopus pulcher kangrae in the NW Himalayas to Kashmir and nominate $P$. p. pulcher covering the whole remaining eastward range (Hartert 1910; Vaurie 1959). Forest breeding habitats of the species cover a broad altitudinal range from median elevations up to subalpine forests occasionally above $4000 \mathrm{~m}$ including some downhill movements outside the breeding season (Clement 2006). Local breeding records from Nepal cover a rather narrow range from between 3250 up to $4100 \mathrm{~m}$ a. s.l. and wintering records suggest local movements from beginning of October down to 1400-2700 m a.s.l. (Martens and Eck 1995). For the drier western Himalayas, Price et al. (2003) give breeding range limits at slightly lower elevations between 3050 and $3500 \mathrm{~m}$ a.s.l (for the western subspecies kangrae a breeding range between 3250 and $3960 \mathrm{~m}$ is given in Hartert 1932). In Sikkim, the species is highly abundant in conifer and dwarf rhododendron association up to $3960 \mathrm{~m}$ during breeding season with downhill movements in winter (between 1220 and 2130 m; Hartert 1910; Ali 1962). During the breeding season Buff-barred Warblers occupy the coniferous forest belt with Abies, Tsuga and Picea intermixed with Quercus and Rhododendron at the lower limit up to subalpine birch and juniper with some dwarf-rhododendron undergrowth as well as semi-open bush vegetation above treeline (Martens and Eck 1995; Clement 2006).

Presently, nominate P. p. pulcher is considered morphologically uniform with respect to plumage coloration or proportions throughout its entire Sino-Himalayan breeding range (e.g. Clements et al. 2013). However, there was first evidence of subtle differentiation of territorial songs among populations from the Himalayas and from China based on a limited number of sound recordings (Fischer et al. 2011). Accordingly, we at least expect a 
Table 1 Phylogeographic breaks among Himalayan and Chinese sister taxa of Old World warblers (Phylloscopus) indicated by mtDNA genetic distances (cytochrome $b$, in \%)

\begin{tabular}{|c|c|c|c|}
\hline Taxon 1 Himalayas & Taxon 2 China & p-dist & Source \\
\hline Phylloscopus trochiloides trochiloides & Phylloscopus trochiloides obscuratus & 0.4 & Irwin et al. 2001b, 2005; Päckert et al. 2012 \\
\hline Phylloscopus trochiloides ludlowi $\mathrm{W}^{\mathrm{a}}$ & Phylloscopus t. ludlowi E/P. t. trochiloides & 4.3 & Richman 1996; Irwin et al. 2005; Päckert et al. 2012 \\
\hline Phylloscopus fuligiventer fuligiventer & Phylloscopus fuligiventer weigoldi & 1.3 & Martens et al. 2008 \\
\hline Phylloscopus cantator & Phylloscopus ricketti/P. calciatilis & $2.2-3.4$ & Olsson et al. 2005; Päckert et al. 2009a; Alström et al. 2010 \\
\hline Phylloscopus reguloides reguloides ${ }^{b}$ & Phylloscopus reguloides ticehursti & $2.9-3.6$ & Olsson et al. 2005; Päckert et al. 2009b \\
\hline Phylloscopus xanthoschistos ${ }^{c}$ & Phylloscopus davisoni & 3.6 & Olsson et al. 2005; Päckert et al. 2009a \\
\hline Phylloscopus chloronotus ${ }^{\mathrm{d}}$ & Phylloscopus forresti & 4.2 & Martens et al. 2004 \\
\hline Phylloscopus affinis & Phylloscopus occisinensis & 7.4 & Martens et al. 2008 \\
\hline Phylloscopus humei humei & Phylloscopus humei mandellii & $8.7-8.8$ & Irwin et al. 2001a; Päckert et al. 2012 \\
\hline
\end{tabular}

a Local sympatry of members from the two clades proven.

${ }^{\mathrm{b}}$ Including eastern subspecies assamensis.

Including eastern subspecies tephrodiras.

${ }^{\mathrm{d}}$ Including western subspecies simlaensis.

subtle phylogeographic break between Himalayan and adjacent Chinese populations of Phylloscopus pulcher as found in many other leaf warbler species, too. We test this hypothesis using one molecular marker (mitochondrial cytochrome $b$ ) and sonagraphic analysis of an extended data set of song recordings.

\section{Methods}

Molecular genetics and voucher specimen morphology A total of 58 blood or tissue samples of Buff-barred Warblers from Nepal and China were available for molecular analysis (for origin of samples see map in Figure 1 and Additional file 1: Appendix). DNA extraction from blood and tissue samples was performed in a chloroformisoamyl isolation or with a peqLab tissue/blood kit according to the manufacturer's instructions. An approximately 990-bp long fragment of the mitochondrial cytochrome- $b$ gene was amplified using the forward primer L14841 (5'AAA AAG CTT CCA TCC AAC ATC TCA GCA TGA TGA AA-3'; Kocher et al. 1989) and the reverse primer H15917 (5' -TAG TTG GCC AAT GAT GAT GAA TGG GTG TTC TAC TGG TT-3'; Dietzen et al. 2003) under PCR settings according to Dietzen et al. (2003). PCR products were purified by adding $0.2 \mu \mathrm{L}$ ExoSap-IT solution in $4 \mu \mathrm{L}$ distilled water to each sample (cycling program: $37^{\circ} \mathrm{C}$ for $30 \mathrm{~min}$ and $94^{\circ} \mathrm{C}$ for $15 \mathrm{~min}$ ). Sequencing of the PCR products was performed with BigDye ${ }^{\mathrm{Tm}}$ v. 3.0 and v. 3.1 Dye Terminator Cycle Sequencing Kits (Applied Biosystems) according to the manufacturers' instructions. Cycle sequencing products were purified by salt/ethanol precipitation or by using Sephadex (GE Healthcare, München, Germany) and sequenced in both directions on an $\mathrm{ABI}$ 3130xl DNA sequencer. An additional internal reverse primer H15547 (5'-AAT AGG AAG TAT CAT TCG GGT TTG ATG-3'; Edwards et al. 1991) was used for sequencing of some samples. The sequences were aligned by ClustalW using MEGA 4 (Tamura et al. Tamura et al. 2007) and slightly adjusted by eye.

A minimum spanning haplotype network was constructed using TCS (Clement et al. 2000) and pairwise distances were computed using MEGA 4 and genetic diversity parameters and mismatch distributions were estimated using DnaSP v5.1 (Librado and Rozas 2009). Cytochrome- $b$ sequences were deposited on GenBank under accession numbers KJ567540-KJ567596 (Additional file 1: Appendix).

For potential phenotypic distinction among Himalayan and Chinese birds we took morphological measurements from specimens available to us (compare Additional file 1: Appendix) of wing length, tail length, beak length and tarsus length according to the methods given in Eck et al. (2011): wing length $\left(\mathrm{W}_{\max }\right)$ maximum chord, ruler with zero-stop; tail length (T1) taken with divider from the point where the central rectrices meet the skin to longest rectrix tip; tarsus length (Tar1) taken with calipers according to Eck et al. (2011); beak length (Bsk) with divider from tip to skull front.

\section{Bioacoustics}

Buff-barred Warbler songs are quite stereotypic and are usually displayed in a song continuum of distinct verses which are connected by short high-pitched (call like) notes.

Two distinct verse types have been described for Nepalese populations by Martens (1980): rattling trill verse types and warbling verse types (Figure 2). In fact, the different auditory impressions of trills and warbles were already recognized as distinct song parts by Hartert (1932). Both types can be displayed separately in long series by one male, but also in quick alteration, thus both together seem to be likewise relevant in territorial context and are typically combined to long continuous song displays. The high-pitched trills consist of a series of rapidly repeated short and steeply descending elements 


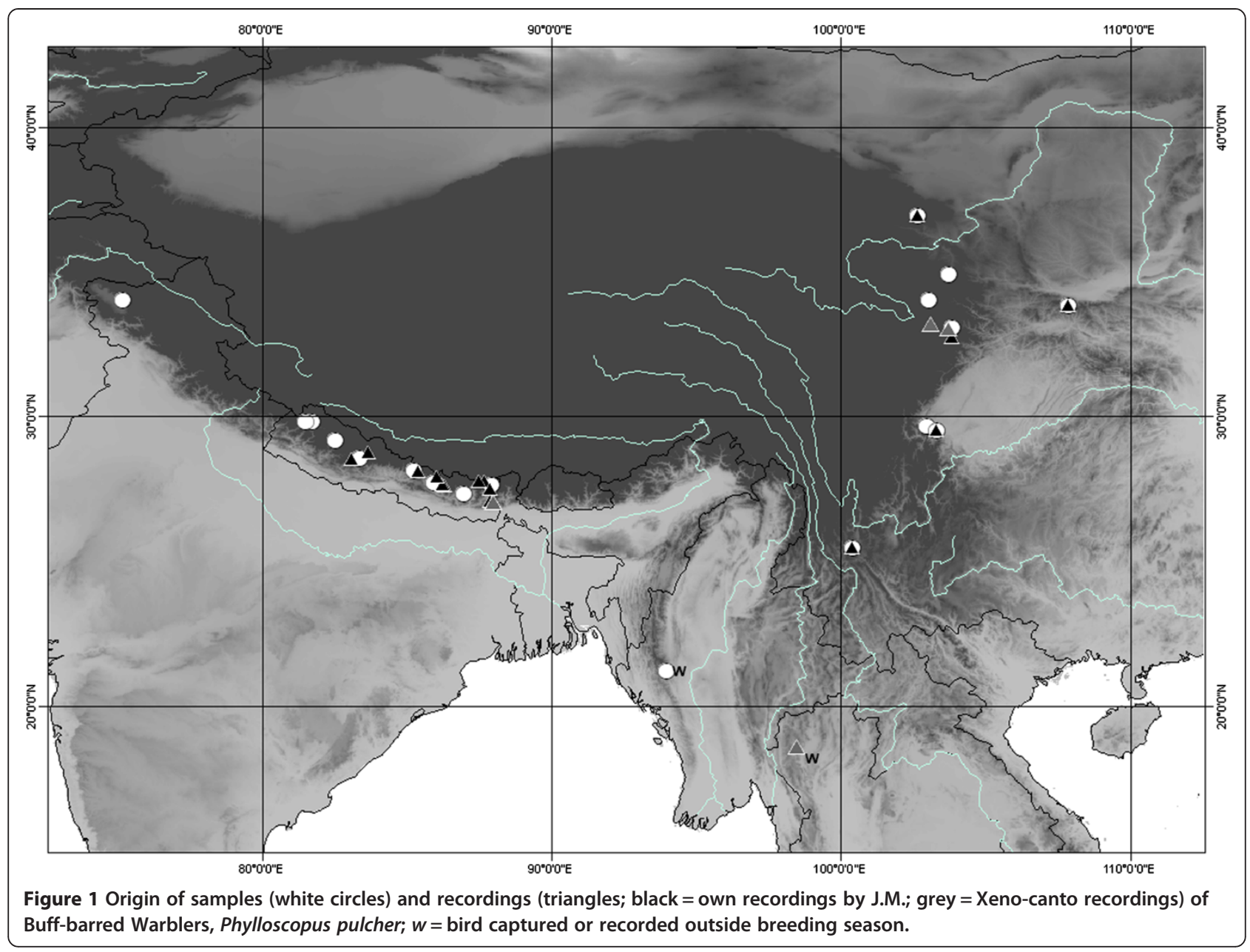

of the same type (Figure 2a) and have been commonly described as similar to songs of the Wood Warbler (P. sibilatrix), and of the Brooks's Leaf Warbler (P. subviridis) (Martens 1980; Clement 2006). Even though trills do not necessarily predominate in male territorial behavior and courtship, this verse type seems to be commonly regarded as the typical vocalization of $P$. pulcher and it is only this type that has been listed for this species in Clement (2006); also in Williamson (1976). In contrast, warbling song types of $P$. pulcher have been described as long series of repeated syllables consisting of two elements of syntax $A B A B A B$ and

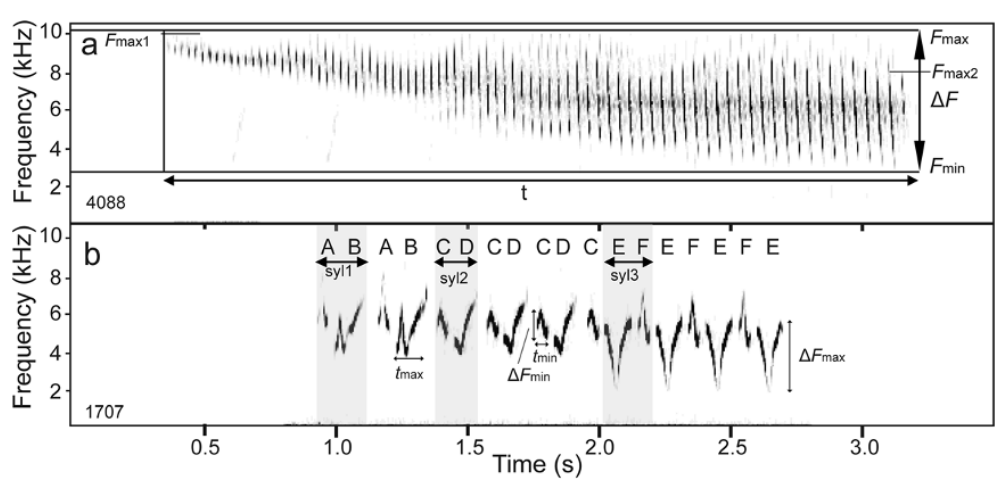

Figure 2 Sonagraphic measurements taken from trill verse types (a) and warbling verse types (b), the latter being composed of repeated syllables (syl1, syl2, syl3) of alternating elements ( $A B, C D, E F)$; recordings J.M.: 4088: China, Shaanxi Taibai Shan; 1707: Nepal, Thankur N Dhorpatan. 
often songs are divided into distinct parts combining different syllables of syntax ABABCDCDCD (Figure 2b; compare Martens 1980). Because different syllables can be combined in warbling songs, they are more variable within and between males compared to trill songs ( 2 to 5 different warbling song types per individual male; Martens 1980). Both trill and warbling song types are introduced by a short call-like click note that is a typical structure of other leaf warbler songs, too (Päckert et al. 2009b). The human ear can hardly distinguish the songs from either areas; it is unable to resolve the distinct patterns of warbling song parts (recordings from Nepal and China documented in Martens (2013)).

Prior to sonagraphic analyses all original recordings were converted to wave format with a sampling rate of $22.1 \mathrm{kHz}$ and in 16 bit mono and analyzed with Avisoft SASLab Light v3.74 (Specht 1996). Sonagraphic measurements were taken for individual verse types (trills and warbles) excluding the introductory click note. The following parameters were measured (compare Figure 2): maximum frequency of the whole verse, of the first and the last note $\left(F_{\max }, F_{\max 1}, F_{\text {maxend }}\right)$, minimum frequency and frequency span of verse $\left(F_{\min }, \Delta f=F_{\max }-F_{\min }\right)$, frequency course of verse from the first to the last element $\left(\Delta F_{\max }=F_{\text {maxend }}-F_{\max 1}\right)$, total duration of verse $(t)$ plus maximum and minimum duration of longest and shortest element $\left(t_{\max }, t_{\min }\right)$, maximum and minimum frequency bandwidth of broadest and narrowest element $\left(\Delta f_{\max }\right.$, $\left.\Delta f_{\text {min }}\right)$, total number of elements $(z)$ and of different element types $\left(z_{\mathrm{el}}\right)$. Tempo of verses was calculated as a function of a) total number of elements per time unit $(z / t$; speed) or b) number of repeated units (elements or syllables) per time unit (repetition rate). A maximum of five verses per type (trills and warbles) were measured for the individual male and means were calculated separately for each the two verse types of each male. Among- and within-species differentiation of verse types was analyzed using principal-component analysis and discriminant analysis with SPSS 11.5.

\section{Results}

\section{Mitochondrial DNA}

The 817-bp long alignment of 56 original sequences and four further sequences from GenBank (Additional file 1: Appendix) included 44 variable sites of which 17 were parsimony informative. The minimum-spanning network is shown in Figure 3. The network was divided into two distinct clusters which clearly corresponded to the geographic origin of samples. The Himalayan cluster comprised 15 haplotypes arranged in a star-like cluster with the central haplotype being the most common one and present in 14 individuals from all populations. All other haplotypes were private haplotypes found in a single individual only. Tip haplotypes differed at a maximum of three substitutions from the center of the network including one haplotype of subspecies kangrae (GenBank sequence, sample from Kashmir) which was firmly nested in the Himalayan cluster (Figure 3).

The Himalayan cluster was separated by a minimum of six substitutions from a second cluster including all sequences from Chinese samples and two samples from Myanmar (the maximum difference among tip haplotypes was 15 substitutions; Figure 3). The latter Burmese birds were captured in March and must be considered winter visitors/spring migrants from a Chinese population (Figure 1). Genetic diversity of the Chinese cluster is somewhat higher compared to the Himalayan ones (Figure 3): Among all Chinese samples, 20 haplotypes were found and most common haplotypes were present in six, four and three individuals, respectively. Haplotype diversity $(\mathrm{HD})$ and nucleotide diversity $(\pi)$ were both higher in the Chinese population than in the Himalayan population: $\mathrm{HD}_{\text {China }}=0.947 \pm 0.023, \quad \mathrm{HD}_{\text {Nepal }}=0.717 \pm 0.103$; $\pi_{\text {China }}=0.0037 \pm 0.0004, \quad \pi_{\text {Nepal }}=0.0016 \pm 0.0004$. Both geographical subsamples showed strictly unimodal mismatch distributions corresponding to a growth-decline model, but only the Nepal-Himalayan population had a significantly negative Tajima's $D$ indicating past population expansion (Figure 3). However, both Fu and Li's $D$ and $F$ statistics were significantly negative for the Chinese population, too $(D=-3.025, p<0.05 ; F=-3.052, p<0.05)$. The mean genetic distance between the Himalayan and the Chinese cluster was $1.2 \%$ compared to within-group distances of $0.4 \%$ for each of both clusters. The mean genetic distance between one sample of subspecies kangrae and the samples of nominate pulcher from Nepal ranged at 0.3\%.

\section{Morphology}

We compared 19 specimens from the Himalayas (W to E Nepal, 1999-2003) to 11 from China (Sichuan, Gansu; 5 from 1914, 6 from 1998-2007), all from the breeding season (May to early July). Except for one Chinese bird (from 30 July) all birds were adults and not in moulted plumage. Specimens from both regions were pretty similar in plumage coloration of underpart and identical in upperpart coloration. Slight differences are only noticeable in a series. Nepal: Throat and breast light grey noticeably interspersed with scattered yellow feathers causing patchy ornamentation, towards broad middle of belly vividly yellowish-greenish, sides of belly, flanks, in continuation of throat and belly light greyish. China: Similar to nominate pulcher from Nepal, throat and breast grey but distinctly more homogeneously darker stone grey with hardly any yellow feathers, no patchy distribution of greyish-greenish markings like in specimens from Nepal; middle of belly less vividly yellowishgreen than in Himalayan specimens, flanks similar in specimens from both regions. 

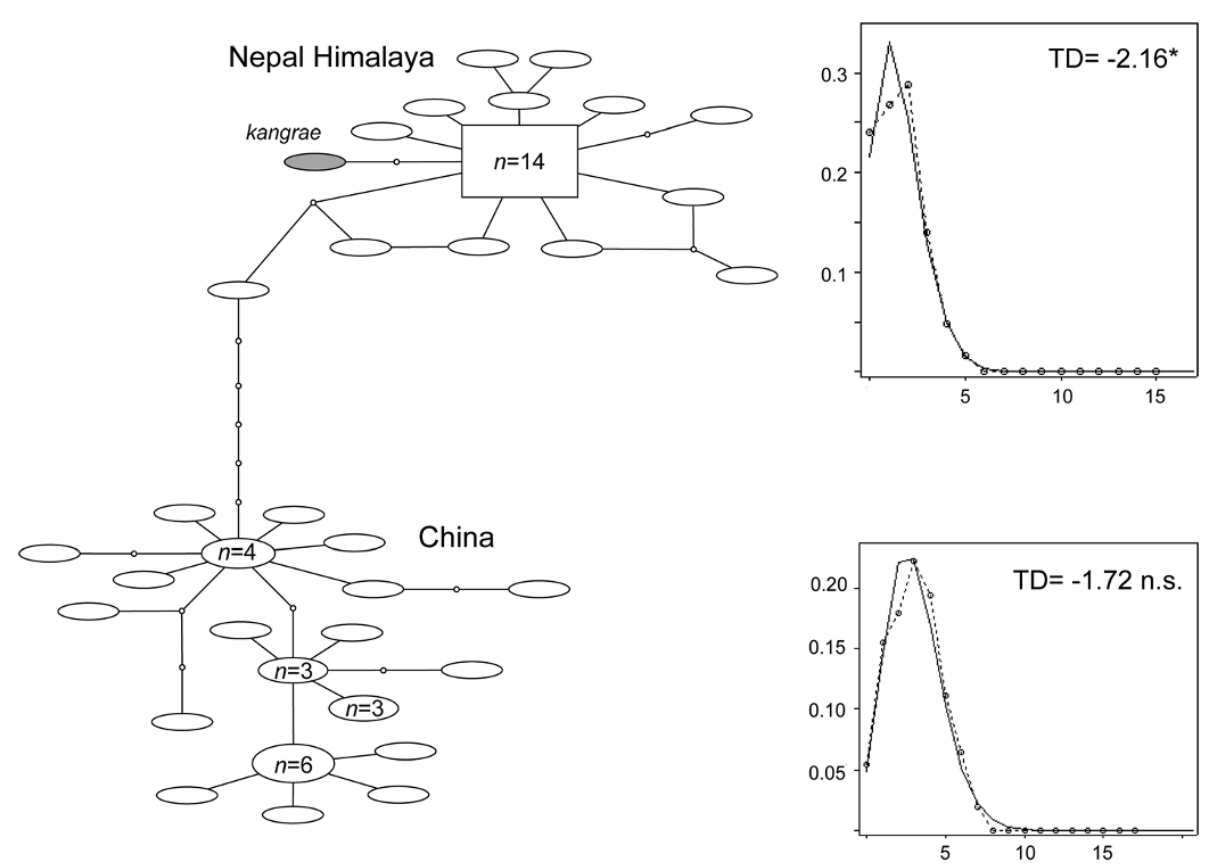

Figure 3 Minimum-spanning haplotype network based on a 817-bp long alignment of the mitochondrial cytochrome- $b$ gene $(n=60)$; size of ovals corresponds to frequency of haplotypes (indicated for $n>2$ for most common haplotypes); small dots $=$ hypothetical haplotypes connecting (sub) clusters or tip haplotypes; mismatch distributions for the two larger clusters (Nepal-Himalaya and China) and Tajima's D statistics shown on the right. ${ }^{* *}=p<0.01$.

Measurements: No significant differences in body size dimensions (wing length, tail length, tarsus length and beak length) were found among populations from China and from the Nepal Himalayas (Mann-Whitney U test; > 0.05, n.s.). It made no difference whether all measures were pooled or analysed separately for sexes. Males were significantly larger than females in wing, tail and beak dimensions but not in tarsus dimensions (Table 2; Mann-Whitney $\mathrm{U}$ test, $p<0.01$, pooled measurements of all Himalayan and Chinese specimens).

\section{Territorial songs}

A total of 168 verses of 29 individual males (45 means of individual verse types, trills and warbles) were measured and included in our analysis. Trill verse types had the same structure all over the entire range of the species $(n=28)$ while warbling verse types were structurally more complex and variable throughout the trans-Sino-Himalayan range (Figure 4). Differences among regions were subtle, but significant for most frequency and time parameters (only three out of eleven parameters were not significantly different among regions: duration, maximum frequency and minimum element range; Mann-Whitney U-test, n.s.).

The first three principal components had eigenvalues greater than one and $\mathrm{PC} 1$ explained $46.8 \%$ of the total variation (PC2 explained a cumulative $62.6 \%$ and $\mathrm{PC} 3$ a cumulative $74.2 \%$ of the total variation). Scatterplots of PC1 vs. PC2 and PC3, respectively, showed individual trills clustering according to the two regions (Figure 5). On average Chinese trills ranged at significantly lower minimum frequencies and covered a significantly broader frequency range (Mann-Whitney U-test, $p<0.01$; Table 3 ). Trills of Chinese males were significantly more rapid compared to slower trills in Himalayan populations (MannWhitney U-test, $p<0.01$ ) and they have a significantly steeper frequency decrease towards the end (Table 3). Trill notes of Chinese verses were significantly shorter and cover a significantly broader frequency range (only $\Delta f_{\max }$ ) than trill notes of Nepalese verses (Table 3).

Warbling verses of Himalayan males (Figure 4) were structurally complex including steady repetitions of one syllable (syntax: $A B A B A B A B$ ), two syllables $(A B A B$ $A B C D C D C D)$ and even three syllables $(A B A B A B$ CD CD CD EF EF EF). Despite very similar auditory impression, Chinese warbles were distinctive against those from the Himalayas comprising only repeated single elements instead of syllables (syntax: AAAAA, AAA BBB or AAA BBB CCC; Figure 4d). The strong frequency modulation of the single element in Chinese verse types (v-shaped or w-shaped in the sonagram) is the reason for their warbling sound quality, although these song types do not contain syllables of alternating notes. No repetitions of syllables were found in Chinese warbles and no repetitions of single elements were found in Himalayan warbles, respectively. In contrast to trill verse types, warbling verse types did not show strong differences of continuous 
Table 2 Body size dimensions of Buff-barred Warblers (Phylloscopus pulcher) from the Himalayas and China (all in mm); means and standard deviations [range of individual measures]

\begin{tabular}{lllll}
\hline Population/sex & Wing & Tail & Tarsus & Beak \\
\hline Nepal/males $(n=14)$ & $59.4 \pm 1.8[56.0-62.5]$ & $43.1 \pm 1.9[40.0-45.8]$ & $19.1 \pm 1.2[16.4-20.0]$ & $11.3 \pm 0.7[10.0-13.0]$ \\
Nepal/females $(n=5)$ & $53.0 \pm 2.9[50.0-58.0]$ & $40.2 \pm 1.0[38.5-41.0]$ & $18.4 \pm 1.3[17.0-20.2]$ & $10.4 \pm 0.6[9.5-10.8]$ \\
China/males $(n=7)$ & $59.6 \pm 1.8[58.0-62.0]$ & $44.0 \pm 1.4[42.5-46.5]$ & $18.7 \pm 1.1[17.0-20.0]$ & $11.0 \pm 0.7[10.0-12.0]$ \\
China/females $(n=3)$ & $55.5 \pm 1.3[55.0-57.0]$ & $40.7 \pm 2.0[39.0-43.0]$ & $17.9 \pm 0.2[17.7-18.0]$ & $10.0 \pm 0,06[10.0-10.1]$ \\
\hline
\end{tabular}

frequency and time parameters among regions. Only four out of twelve parameters differed between Chinese and Himalayan warbles and all of these corresponded to the more complex structure of the latter including syllables of alternating short and long elements. Compared to Himalayan populations, warbling songs from Chinese populations are significantly slower and less variable with respect to different element types per single verse (Table 3). Note types of Chinese verses are significantly longer (only $t_{\mathrm{min}}$ ) and cover a significantly broader frequency range (only $\Delta f_{\text {min }}$ ) compared to Nepalese note types (Table 3 ).

Rarely, mixed verse types have been found in single individuals combining trills followed by a short warbling part in both regions (Figure $4 \mathrm{~h}, \mathrm{i}$ ).

\section{Discussion}

Phylogeography

According to our expectations we confirmed a SinoHimalayan East-West divide in the Buff-barred Warbler,

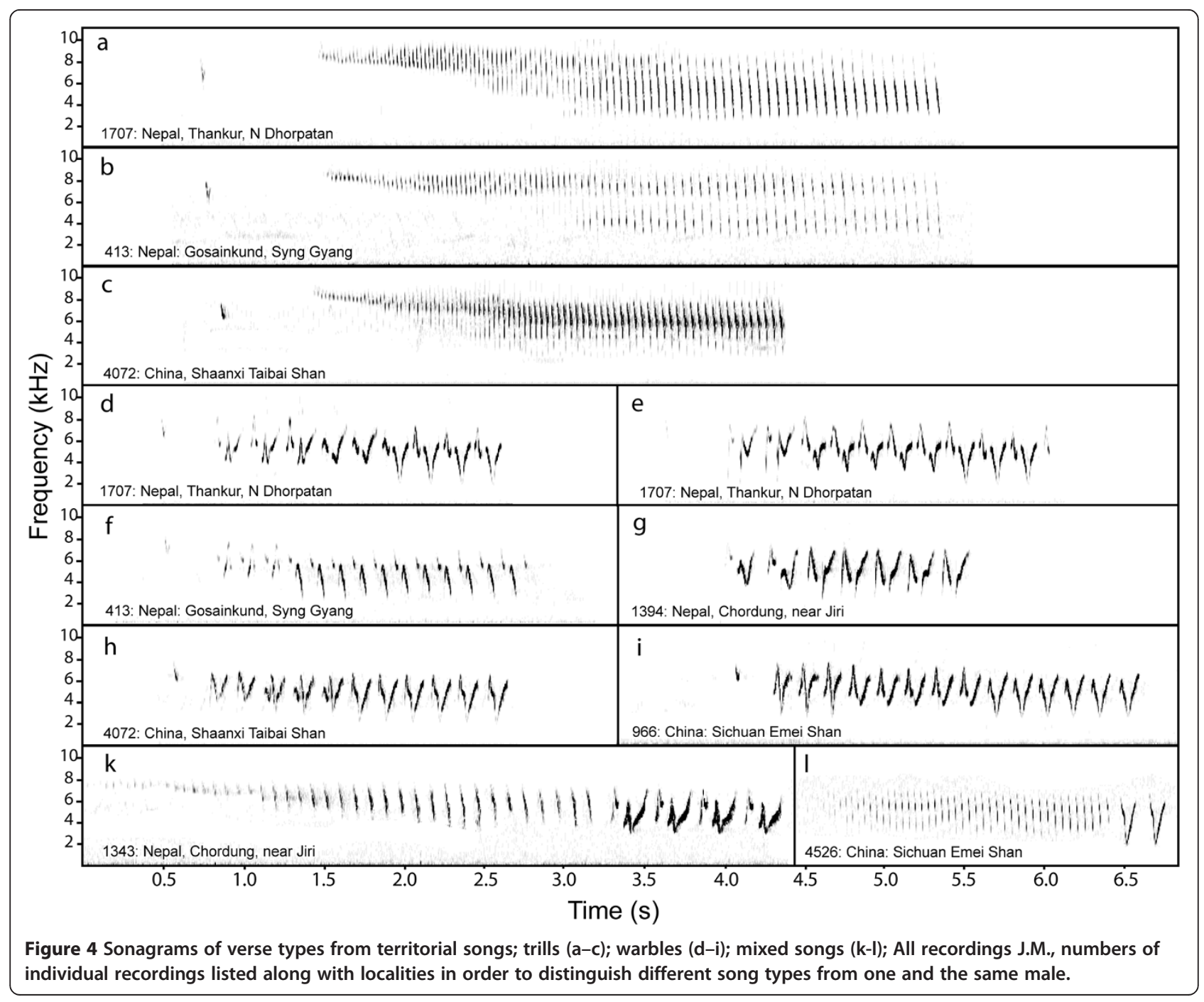



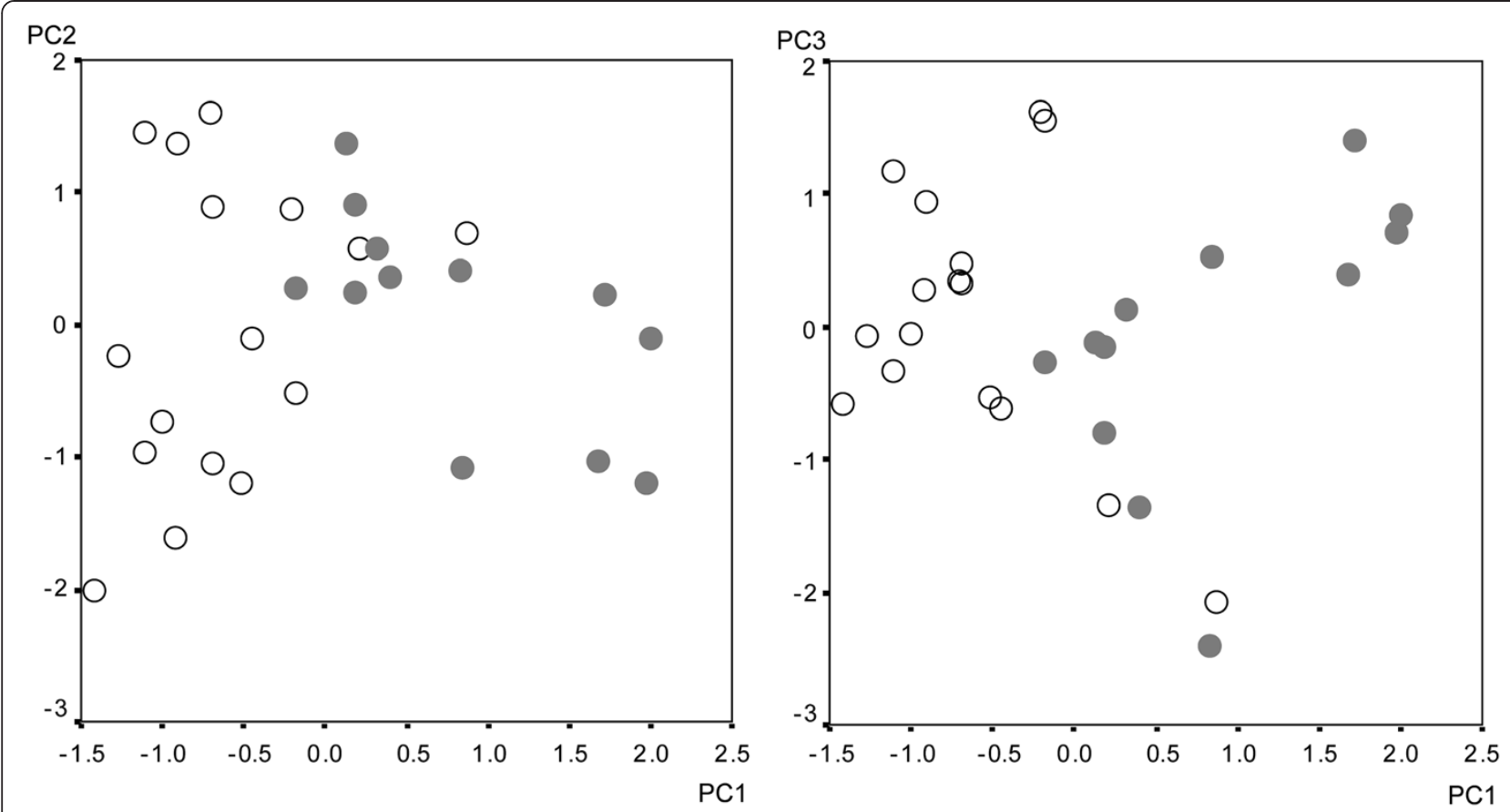

Figure 5 Principal-component analysis: scatterplots of PC1 vs. PC2 (left) and PC1 vs. PC3 respectively (right) for 28 individual trill songs. PC1 increases with speed of trill, frequency range and maximum frequency descent. (White circle) $=$ Nepal, (grey circle) $=$ China.

P. pulcher. Assuming an empirical substitution rate of 0.0105 substitutions per lineage, site and million years (approximately 2\% among lineages for cytochrome $b$, Weir and Schluter 2008) the respective genetic distance of $1.2 \%$ corresponds to a late Pleistocene separation among Himalayan and Chinese mtDNA lineages roughly 650000 years ago. This value compares to intraspecific distances in other leaf warbler taxon pairs showing the same phylogeographic break (e.g. P. f. fuligiventer/P. $f$. weigoldi: Table 1; Martens et al. 2008) and even to interspecific distances among sister species of leaf warblers: Phylloscopus ogilviegranti and P. hainanus; Seicercus grammiceps and $S$. castaniceps (both pairs having a cytochrome- $b$ distance of 1.5\%; Olsson et al. 2004, 2005; Päckert et al. 2004, 2009b).

East-West divides across the southern and south-eastern QTP margin are a quite general pattern in forest-dwelling passerines and many of them date back to Pleistocene impact on differentiation processes in disjunct forest refuges (Martens et al. 2011; Päckert et al. 2012). Typically, Himalayan taxa might be genetically less diverse than their respective Chinese counterparts due to a loss of genetic variation in smaller, strongly isolated Himalayan refuge populations (Päckert et al. 2009a). This is partly reflected by slight differences of genetic diversity parameters and haplotype network structure in $P$. pulcher, but a broader sampling would be required to substantiate these findings. Likewise, the eastward extent of the Himalayan haplogroup of $P$. pulcher and possible secondary contact with the Chinese haplogroup cannot be reliably confirmed due to a wide sampling gap in the eastern Himalayas and southern China. Thus further study of material particularly from south-western Chinese provinces (particularly SW Yunnan and SE Tibet) and adjacent areas in N Myanmar and NW India is required. In fact, secondary overlap of distinct mtDNA lineages in the latter region has been demonstrated for tits and long-tailed tits, Paridae and Aegithalidae (Dai et al. 2011; Zhao et al. 2012; Wang et al. 2013a, 2013b) and can be hypothesized for other leaf warbler taxa, too (e.g. for P. xanthoschistos and P. davisoni, $P$. r. reguloides (incl. assamensis) and $P$. r. ticehursti; Olsson et al. 2005; Päckert et al. 2009b, 2012).

Along the southern QTP margin in the Himalayas, East-West divides and secondary contact between mtDNA lineages were documented for different regions and at different degrees of genetic divergence. In the Central Himalayas, Martens and Eck (1995) defined four subspecies transition areas that largely correspond to intraspecific splits among mtDNA sister lineages, e.g. in Periparus tits ( $P$. ater in the Dhaulagiri transition area and P. rubidiventris in the Kathmandu transition area). In contrast, secondary overlap in the Western Himalayas often corresponds to a faunal transition among Central Asian and Himalayan faunal elements that correspond to deeper and older phylogenetic splits (and do not even represent sister clades); e.g. Periparus rufonuchalis/P. rubidiventris (Martens et al. 2006); Aegithalos leucogenys/Ae. concinnus, Ae. niveogularis/Ae. iouschistos (Päckert et al. 2010). 


\section{Table 3 Mean values (plus standard deviations) of frequency and time parameters of trill song and warbling song of Phylloscopus pulcher}

\begin{tabular}{|c|c|c|c|c|c|c|c|c|c|c|c|c|c|}
\hline \multicolumn{14}{|l|}{ Trill song } \\
\hline Population & $n$ & tges & $\left.z e\right|^{* *}$ & speed $^{* *}$ & zeltype $e^{* *}$ & $t_{\max }^{* *}$ & $t_{\min }^{* *}$ & $F_{\max }$ & $F_{\min }^{* *}$ & $\Delta f^{* *}$ & $\Delta f_{\max }^{*}$ & $\Delta f_{\min }$ & $f_{\text {mod }}{ }^{* *}$ \\
\hline China & 12 & $3.25 \pm 0.42$ & $96.4 \pm 13.5$ & $29.6 \pm 1.4$ & $1.4 \pm 0.5$ & $0.03 \pm 0.004$ & $0.01 \pm 0.001$ & $9.77 \pm 0.71$ & $2.93 \pm 0.23$ & $7.00 \pm 0.74$ & $5.64 \pm 0.87$ & $0.87 \pm 0.37$ & $-1.9 \pm 0.71$ \\
\hline Nepal & 16 & $3.32 \pm 0.92$ & $70.6 \pm 20.7$ & $21.4 \pm 2.1$ & $1.0 \pm 0.1$ & $0.05 \pm 0.012$ & $0.02 \pm 0.016$ & $9.37 \pm 0.51$ & $3.56 \pm 0.58$ & $5.81 \pm 0.77$ & $4.97 \pm 0.88$ & $0.73 \pm 0.27$ & $-0.9 \pm 0.83$ \\
\hline \multicolumn{14}{|c|}{ Warbling song } \\
\hline Population & $n$ & tges & zel & speed $^{* *}$ & zeltype* & $t_{\max }$ & $t_{\min }^{* *}$ & $F_{\max }$ & $F_{\min }$ & $\Delta f$ & $\Delta f_{\max }$ & $\Delta f_{\min }^{* *}$ & $f_{\text {mod }}$ \\
\hline China & 9 & $1.76 \pm 0.24$ & $12.1 \pm 3.0$ & $6.9 \pm 1.3$ & $2.5 \pm 0.7$ & $0.13 \pm 0.009$ & $0.09 \pm 0.028$ & $7.46 \pm 0.38$ & $2.42 \pm 0.26$ & $5.04 \pm 0.44$ & $4.75 \pm 0.44$ & $3.36 \pm 0.62$ & $-0.4 \pm 0.32$ \\
\hline Nepal & 8 & $1.61 \pm 0.27$ & $15.9 \pm 6.2$ & $9.7 \pm 2.3$ & $3.4 \pm 0.9$ & $0.11 \pm 0.028$ & $0.05 \pm 0.009$ & $7.72 \pm 0.60$ & $2.43 \pm 0.44$ & $5.30 \pm 0.99$ & $4.36 \pm 0.91$ & $2.05 \pm 0.76$ & $-0.3 \pm 0.41$ \\
\hline
\end{tabular}

$\mathrm{n}=$ number of individual male recordings measured; significant differences among Chinese and Himalayan (Nepal) populations: ${ }^{*}=$ Mann-Whitney-U test, $\mathrm{p}<0.05$;

** = Mann-Whitney-U test, $\mathrm{p}<0.01$. 
To date only a few Asian passerine species were shown to have a homogeneous mitochondrial gene pool across the entire southern and south-eastern QTP margin, e.g. Pyrrhula nipalensis (Töpfer et al. 2011). Intraspecific mtDNA differentiation might also be absent in two further leaf warbler species (P. maculipennis, P. magnirostris), but this remains to be verified. Furthermore, mtDNA phylogeographies have limited explanatory power, because nuclear gene flow might widely extend beyond the limits of phylogeographic mtDNA divides as in the Greenbacked Tit (Parus monticolus) (Wang et al. 2013a, 2013b).

\section{Taxonomy}

For the Chinese populations of the Buff-barred Warbler the name Reguloides pulcher vegetus Bangs 1913 is available. The original description was based on three specimens from W Sichuan collected by W. R. Zappey. The holotype was collected at Yachiakun on July 14, 1908, by W. R. Zappey on $3810 \mathrm{~m}$ a.s.l. Bangs later compared the material from Zappey with two specimens from Sikkim which he considered to be "very different from the Chinese bird" (Bangs 1913). According to Bangs' description his newly described $P$. p. vegetus should be "much paler and duller in color throughout" compared to nominate pulcher from the Himalayas with some slight differences in yellow underpart and rump patch coloration, too. Later on, Chinese $P . p$. vegetus received a tentative treatment only by taxonomists (e.g. Hartert 1932), presumably due to a lack of significant material for comparison. Riley (1931) considered all Chinese specimens belonging to subspecies vegetus until further revisiting of specimens from Nepal. Greenway (1933) analysed seven Buff-barred Warbler specimens from Yunnan and Tibet and considered them even "slightly darker and greener below than the type of vegetus" and concluded that for the time being he had insufficient Indian material at hand for comparison. Most subsequent taxonomic authorities synonymized that taxon with the nominate form P. p. pulcher (Ticehurst 1938; Vaurie 1959) and, in his field guide, Williamson (1976) considered the Chinese form vegetus "not separable from the typical race". Thus, in current taxonomy $P . p$. vegetus is not recognized as a valid subspecies anymore (Cheng 1987; Dickinson 2003; Clements et al. 2013). In fact, we could confirm morphological distinctiveness of Chinese P. $p$. vegetus only for subtle differences from Himalayan birds in plumage coloration but not by metric morphological traits of specimens examined. Our mean values of morphological parameters were fully congruent with body size dimensions listed for birds from Sikkim by Ali (1962) and for birds from Nepal by Martens and Eck (1995). Differences among sexes were already documented for Nepal birds by Eck and Martens (1995) but based on different material than analyzed here.
Compared to Himalayan populations of subspecies $P$. p. pulcher and P. p. kangrae, Chinese $P$. p. vegetus has more homogeneously dark greyish throat and breast plumage with hardly any yellow feathers and underparts less vividly yellowish-green. In addition, warbling song types provide a diagnostic character for subspecies distinction of Chinese vegetus populations for their unique syntax pattern of repeated single notes (AAA BBB CCC) instead of repeated syllables in the Himalayan part of the species breeding range (ABABAB CDCDCD). Apart from subspecies diagnosability solely by song pattern, pairwise distances between Himalayan and Chinese populations notably exceed the intraspecific distance value among NW Himalayan $P$. pulcher kangrae and nominate $P . p$. pulcher from the Central Himalayas.

We therefore recommend revalidation of the name Phylloscopus pulcher vegetus Bangs 1913 for Chinese populations of the Buff-barred Warbler. We refrain from assigning cytochrome- $b$ hapotypes as diagnostic characters and restrict subspecies diagnosis to its subtle phenotypic characteristics and to song pattern of single note repetitions as outlined above. According to our data, the Chinese breeding area of $P$. pulcher vegetus extends from the provinces Gansu and Qinghai in the North across Shaanxi and Sichuan to Yunnan in the South - and possibly even to adjacent subHimalayan N Myanmar in the Southwest (breeding records from this region remain to be confirmed, since our own field records were made outside the breeding season). During the breeding season the birds occupy broad-leaf and mixed forests from mean elevations at $2350 \mathrm{~m}$ to mountain summits at $3200 \mathrm{~m}$ (at Lianhua Shan, Gansu).

Though slight differences between $P . p$. pulcher and $P$. p. vegetus are obvious, the original description of vegetus by Banks differed from the judgment of later authors as outlined above. Though we generally agree with the original morphological diagnosis by Bangs (1913) and use the name vegetus here, a re-examination of the type material is advisable.

\section{Conclusions}

Chinese populations of the Buff-barred Warbler (Phylloscopus pulcher) turned out to be distinctive against their Himalayan counterparts by the structural pattern of warbling song types and by slight differences in plumage colouration. That distinctiveness is backed by a genetic distance of $1.3 \%$ among two separate mitochondrial lineages (cytochrome $b$ ) from the Himalayas and China, respectively, and by significant differentiation of frequency and timely dimensions of trill song types. Based on the notable differentiation of three independent character sets outlined here (morphology, acoustics, genetics) we recommend the revalidation of the taxon name Phylloscopus pulcher vegetus Bangs, 1913 for Chinese populations of the Buff-barred Warbler. 


\section{Additional file}

Additional file 1: Appendix. Origin of samples used for genetic analyses, all collection J.M. (MAR); museum acronyms of voucher specimens: $\mathrm{NME}=$ Museum für Naturkunde Erfurt, Germany; MTD = Senckenberg Natural History Collections Dresden; ZFMK = Zoologisches Forschungsmuseum Alexander Koenig Bonn, Germany.

\section{Competing interests}

The authors declare that they have no competing interests.

\section{Authors' contribution}

MP designed the study, performed all analyses and drafted the manuscript. BF carried out lab work and pilot analysis within the scope of his Diplom thesis. JM provided most samples and sound recordings that he collected over five decades. YHS coordinated all field work in China. DTT co-supervised BF's thesis and provided additional samples. All authors have read and approved the final draft of the paper.

\section{Acknowledgements}

This study was performed within the scope of the Deutsche Forschungsgemeinschaft project funding for PA 1818/3-1 (M.P.) and was supported by further grants to Y.-H. Sun from the National Natural Science Foundation of China, project No. 31272286. J. Martens received annual travel grants from Feldbausch Foundation and Wagner Foundation at Fachbereich Biologie of Mainz University for field research in Asia. Additional samples from Nepal were provided by M. Fischer and M. Hartmann, Naturkundemuseum Erfurt. A. Rauh assisted with molecular lab work. We thank all colleagues for kind support and all institutions for project funding. Results of the Himalaya Expeditions of J. Martens, No. 279. - For No. 278 see: ZooKeys 339: 55-65, 2013.

\section{Author details}

${ }^{1}$ Senckenberg Natural History Collections, Museum of Zoology, Königsbrücker Landstraße 159, D-01109 Dresden, Germany. ${ }^{2}$ Key Laboratory of Animal Ecology and Conservation, Institute of Zoology, Chinese Academy of Science, 100101 Beijing, China. ${ }^{3}$ Institute of Ecology, Evolution and Diversity, Goethe University, Max-von-Laue-Straße 13, 60439 Frankfurt am Main, Germany. ${ }^{4}$ Institute of Pharmacy and Molecular Biotechnology, University of Heidelberg, Im Neuenheimer Feld 364, 69120 Heidelberg, Germany. ${ }^{5}$ Institut für Zoologie, Johannes Gutenberg-Universität, 55099 Mainz, Germany.

Received: 1 August 2014 Accepted: 6 August 2014 Published online: 30 September 2014

\section{References}

Ali S (1962) The Birds of Sikkim. Oxford University Press, Oxford, p 228

Alström P, Olsson U (1999) The Golden-spectacled Warbler: a complex of sibling species, including a previously undescribed species. Ibis 141:545-568

Alström P, Ericson PGP, Olsson U, Sundberg P (2006) Phylogeny and classification of the avian superfamily Sylvioidea. Mol Phylogenet Evol 38:381-397

Alström P, Davidson P, Duckworth JW, Eames JC, Le TT, Nguyen C, Olsson U, Robson C, Timmins R (2010) Description of a new species of Phylloscopus warbler from Vietnam and Laos. Ibis 152:145-168

Alström P, Olsson U, Lei FM (2013) A review of the recent advances in the systematics of the avian superfamily Sylvioidea. Chin Birds 4:99-131

Bangs O (1913) A new warbler from western China. Proc Biol Soc Washington 26:93-94

Cheng T-H (1987) A Synopsis of the Avifauna of China. Parey, Berlin, pp 805-806

Clement P (2006) Buff-barred Warbler-Phylloscopus pulcher. In: del Hoyo J, Elliott A, Christie DA (ed) Handbook of the Birds of the World, vol. 11: Old World Flycatchers to Old World Warblers. Lynx Edicions, Barcelona, pp 657-658

Clement M, Posada D, Crandall KA (2000) TCS: a computer program to estimate gene genealogies. Mol Ecol 9:1657-1660

Clements JF, Schulenberg TS, lliff MJ, Sullivan BL, Wood CL, Roberson D (2013) The eBird/Clements Checklist of Birds of the World: Version 6.8 [http://www.birds. cornell.edu/clementschecklist/]; download on 2013-07-19.

Dai C, Zhao N, Wang W, Lin C, Gao B, Yang X, Zhang Z, Lei F (2011) Profound climatic effects on two East Asian black-throated tits (Ave: Aegithalidae), revealed by ecological niche models and phylogeographic analysis. PLoS One 6:e29329

Dickinson EC (2003) The Howard and Moore complete checklist of birds of the world, 3rd edition. Christopher Helm, London

Dietzen C, Witt H-H, Wink M (2003) The phylogeographic differentiation of the European robin Erithacus rubecula on the Canary Islands revealed by mitochondrial DNA sequence data and morphometrics: evidence for a new robin taxon on Gran Canaria? Avian Sci 3:115-131

Eck S, Martens J (1995) Towards an ornithology of the Himalayas: Systematics, ecology and vocalizations of Nepal birds. Bonner Zoologische Monographien 38. Zoologisches Forschungsinstitut und Museum Alexander Koenig, Bonn, p 445

Eck S, Fiebig J, Fielder W, Heynen I, Nicolai B, Töpfer T, Van den Elzen R, Winkler R, Woog F (2011) Measuring Birds-Vögel vermessen. Deutsche OrnithologenGesellschaft, Halle, p 118

Edwards SV, Arctander P, Wilson AC (1991) Mitochondrial resolution of a deep branch in the genealogical tree for perching birds. Proc R Soc Lond B Bio Sci 243:99-107

Fischer BS, Martens J, Klussmann-Kolb A, Päckert M (2011) Sing ... und ich sage Dir, woher Du kommst! Intraspezifische Strukturierung im Gesang von zwei asiatischen Laubsängern (Gattung Phylloscopus). Vogelwarte 49:287-288

Greenway JC (1933) Birds for Northwest Yunnan. Bull Mus Comp Zool 74:106-178

Hartert E (1910) Die Vögel der paläarktischen Fauna. Friedländer und Sohn, Berlin, pp 524-525

Hartert E (1932) Die Vögel der paläarktischen Fauna - Ergänzungsband. Friedländer und Sohn, Berlin, pp 250-251

Helbig AJ, Seibold I, Martens J, Wink M (1995) Genetic differentiation and phylogenetic relationships of Bonelli's warbler Phylloscopus bonelli and green warbler P. nitidus. J Avian Biol 26:139-153

Helbig AJ, Martens J, Seibold I, Henning F, Schottler B, Wink M (1996) Phylogeny and species limits in the Palaearctic chiffchaff Phylloscopus collybita complex: mitochondrial genetic differentiation and bioacoustic evidence. Ibis 138:650-666

Irwin DE, Alström P, Olsson U, Benowitz-Fredericks ZM (2001a) Cryptic species in the genus Phylloscopus (Old World leaf warblers). Ibis 143:233-247

Irwin DE, Bensch S, Price TD (2001b) Speciation in a ring. Nature 409:333-337

Irwin DE, Bensch S, Irwin JH, Price TD (2005) Speciation by distance in a ring species. Science 307:414-416

Johansson US, Alström P, Olsson U, Ericson PGP, Sundberg P, Price TD (2007) Build-up of the Himalayan avifauna through immigration: A biogeographical analysis of the Phylloscopus and Seicercus warblers. Evolution 61:324-333

Kocher TD, Thomas WK, Meyer A, Edwards SV, Pääbo S, Villablanca FX, Wilson AC (1989) Dynamics of mitochondrial DNA evolution in animals: amplification and sequencing with conserved primers. Proc Natl Acad Sci U S A 86:6196-6200

Librado P, Rozas J (2009) DnaSP v5: A software for comprehensive analysis of DNA polymorphism data. Bioinformatics 25:1451-1452

Martens J (1980) Lautäußerungen, verwandtschaftliche Beziehungen und Verbreitungsgeschichte asiatischer Laubsänger (Phylloscopus). Adv Ethol 22:1-71

Martens J (2010) A preliminary review of the leaf warbler genera Phylloscopus and Seicercus. Systematic notes on Asian birds: 72. Br Orn Club Occas Publs 5:41-116

Martens J (2013) Vocalizations of Leaf-warblers and Spectacled Warblers (Phylloscopus and Seicercus). Double audio CD, No. SX 419 726. Syrinx Tonstudio, Berlin [http://www.syrinx-ton.de]

Martens J, Eck S (1995) Towards an Ornithology of the Himalayas: Systematics, Ecology and Vocalizations of Nepal Birds. Bonn Zool Monogr 38:1-445

Martens J, Eck S, Päckert M, Sun Y-H (1999) The Golden-spectacled Warbler Seicercus burkii - a species swarm. Zool Abh Mus Tierk Dresden 50:282-327

Martens J, Tietze DT, Eck S, Veith M (2004) Radiation and species limits in the Asian Pallas's Warbler complex (Phylloscopus proregulus s.l.). J Ornithol 145:206-222

Martens J, Tietze DT, Sun Y-H (2006) Molecular phylogeny of Parus (Periparus), a Eurasian radiation of tits (Aves: Passeriformes: Paridae). Zool Abh Mus Dresden 55:103-120

Martens J, Sun Y-H, Päckert M (2008) Intraspecific differentiation of SinoHimalayan bush-dwelling Phylloscopus leaf warblers, with description of two new taxa ( $P$. fuscatus, P. fuligiventer, P. affinis, P. armandii, P. subaffinis). Vert Zool 58:233-265

Martens J, Tietze DT, Päckert M (2011) Phylogeny, biodiversity, and species limits of passerine birds in the Sino-Himalayan region - a critical review. Orn Monogr 70:64-94

Olsson U, Alström P, Sundberg P (2004) Non-monophyly of the avian genus Seicercus (Aves: Sylviidae) revealed by mitochondrial DNA. Zool Scr 33:501-510 
Olsson U, Alström P, Ericson PGP, Sundberg P (2005) Non-monophyletic taxa and cryptic species - evidence from a molecular phylogeny of leaf-warblers (Phylloscopus, Aves). Mol Phylogenet Evol 36:261-276

Päckert M, Martens J, Sun Y-H, Veith M (2004) The radiation of the Seicercus burkii complex and its congeners (Aves, Sylviidae): molecular genetics and bioacoustics. Org Divers Evol 4:341-364

Päckert M, Blume C, Sun Y-H, Wei L, Martens J (2009a) Acoustic differentiation reflects mitochondrial lineages in Blyth's Leaf Warbler and White-tailed Leaf Warbler complexes (Aves: Phylloscopus reguloides, Phylloscopus davisoni). Biol $J$ Linn Soc 96:584-600

Päckert M, Martens M, Sun Y-H, Tietze DT (2009b) Phylogeography and the evolutionary time-scale of passerine radiations in the Sino-Himalayan region (Aves: Passeriformes). In: Hartmann M, Weipert J (ed) Biodiversität und Naturausstattung im Himalaya III. Verein der Förderer und Freunde des Naturkundemuseums Erfurt e.V, Erfurt, pp 71-80

Päckert M, Martens J, Sun Y-H (2010) Phylogeny of long-tailed tits and allies inferred from mitochondrial and nuclear markers (Aves: Passeriformes, Aegithalidae). Mol Phylogenet Evol 55:952-967

Päckert M, Martens J, Sun Y-H, Severinghaus LL, Nazarenko AA, Ting J, Töpfer T, Tietze DT (2012) Horizontal and elevational phylogeographic patterns of Himalayan and Southeast Asian forest passerines (Aves: Passeriformes). J Biogeogr 39:556-573

Price TD (2010) The roles of time and ecology in the continental radiation of the Old World leaf warblers (Phylloscopus and Seicercus). Philos Trans R Soc Lond B Biol Sci 365:1749-1762

Price TD, Zee J, Jamdar K, Jamdar N (2003) Bird species diversity along the Himalaya: a comparison of Himachal Pradesh with Kashmir. J Bombay Nat Hist Soc 100:394-410

Rheindt FE (2006) Splits galore: the revolution in Asian leaf-warbler systematics. Bird Asia 5:25-39

Richman AD (1996) Ecological diversification and community structure in the Old World leaf warblers (genus Phylloscopus): a phylogenetic perspective. Evolution 50:2461-2470

Riley JH (1931) A second collection of birds from the Provinces of Yunnan and Szechwan, China, made for the National Geographic Society by Dr Joseph F. Rock. Proc United States Natl Mus 80:1-91

Specht R (1996) Avisoft-Sonagraph Pro - sonagraphic analysis under Windows. Bioacoustics 6(4):308

Tamura K, Dudley J, Nei M, Kumar S (2007) MEGA4: Molecular Evolutionary Genetics Analysis (MEGA) software version 4.0. Mol Biol Evol 24:1596-1599

Ticehurst CB (1938) A systematic review of the genus Phylloscopus. Trustees of the British Museum, London

Töpfer T, Haring E, Birkhead TR, Lopes RJ, Liu Severinghaus L, Martens J, Päckert M (2011) A molecular phylogeny of bullfinches Pyrrhula Brisson, 1760 (Aves: Fringillidae). Mol Phylogenet Evol 58:271-282

Vaurie C (1959) The birds of the Palearctic fauna — A systematic reference, Order Passeriformes. HF \& G Witherby, London, p 283

von Vietinghoff-Scheel E (1984) Phylloscopus pulcher Blyth. Weißschwanzlaubsänger. In: Dathe H, Neufeldt IA (ed) Atlas der Verbreitung palaearktischer Vögel, Lieferung 12. Akademie-Verlag, Berlin

Wang W, Dai C, McKay BD, Zhao N, Li S-H, Lei F (2013a) Microsatellites underestimate genetic divergence in the green-backed tit (Parus monticolus). Chin Birds 4:144-154

Wang W, McKay BD, Dai C, Zhao N, Zhang R, Qu Y, Song G, Li S-H, Liang W, Yang X, Pasquet E, Lei F (2013b) Glacial expansion and diversification of an East Asian montane bird, the green-backed tit (Parus monticolus). J Biogeogr 40:1156-1169

Weir J, Schluter D (2008) Calibrating the avian molecular clock. Mol Ecol 17:2321-2328 Williamson K (1976) Identification for ringers 2: The genus Phylloscopus. British Trust for Ornithology (BTO), Oxford, pp 10-11

Zhao N, Dai C, Wang W, Zhan R, Qu Y, Song G, Chen K, Yang X, Zou F, Lei F (2012) Pleistocene climate changes shaped the divergence and demography of Asian populations of the great tit Parus major: evidence from phylogeographic analysis and ecological niche models. J Avian Biol 43:297-310

doi:10.1186/s40657-014-0002-x

Cite this article as: Päckert et al:: A phylogeographic break and bioacoustic intraspecific differentiation in the Buff-barred Warbler (Phylloscopus pulcher) (Aves: Passeriformes, Phylloscopidae). Avian Research 2014 5:2.

\section{Submit your next manuscript to BioMed Central and take full advantage of:}

- Convenient online submission

- Thorough peer review

- No space constraints or color figure charges

- Immediate publication on acceptance

- Inclusion in PubMed, CAS, Scopus and Google Scholar

- Research which is freely available for redistribution

Submit your manuscript at www.biomedcentral.com/submit 